\title{
Morphometric Analysis and Flash Floods Assessment of River Taraba Basin in Taraba State, Nigeria
}

\author{
Adelalu Temitope Gabriel, \\ Mohammed Bakoji Yusuf, \\ Benjamin Ezekiel Bwadi, \\ Department of Geography, Taraba State University, Jalingo, Taraba State \\ Yakubu G. Clement, \\ Department of Geography, College of Education, Zing, Taraba State
}

Doi:10.19044/esj.2020.v16n20p158 URL:http://dx.doi.org/10.19044/esj.2020.v16n20p158

\begin{abstract}
Morphmetric analysis was conducted for River Taraba Catchments Area in Taraba with an emphasis on its hydrological response to storm events using geospatial techniques. The Study Basin comprises of nine small watersheds. The drainage network is dendritic. RTCA is a $7^{\text {th }}$ order drainage basin, with an area of $15777 \mathrm{~km}^{2}$, having a perimeter of about $959 \mathrm{~km}$. The $\mathrm{L}_{\mathrm{o}}$ value registered was $1.64 \mathrm{~km}$.This denote gentle slope and stretch paths network on the watershed. The mean $\mathrm{R}_{\mathrm{b}}$ varies between 3.0 and 5.14 for the catchment, indicating a transitional zone of geological structure with a less remarkable influence of structural disturbances. Value of drainage density indicates moderate runoff potentials. This depicts geological structures which do not distort the drainage pattern as such. The Basin have long $\mathrm{L}_{\mathrm{b}}$, of $242 \mathrm{~km}$ .This is an indicative of low flooding susceptibility. The elongated the basin length, the little the effect on the extent to which the surface runoff manipulate the basin and been lowered by agents of denudation. Catchment characterizations of the study area and basin morphometry do not typify high flooding susceptibility. Environmental degradation through proliferation of haphazard and uncontrolled development within and around the flood plain seems the cause of incessant flooding in the catchments. Hazards occur when people place themeselves in the path of geophysical and climatological agents. Governments should discourage influx to buffer and exploitation of the drainage basin in the study area.
\end{abstract}

Keywords: Catchment area, GIS, Morphometric Parameters, River Taraba, Flood Control 


\section{Introduction}

As climate change infiltrate and influence every sphere of the globe, the continuous assessment of the drainage basin as a fundamental geomorphic unit in water resources development and management cannot be relegated. Information on the morphometric features is pivotal to the management of basin. Importance and derivation of quantitative information on basins' features have long been recognized but early bidders utilized traditional (Horton, 1945, Schumm, 1956; Hadley and Schumm, 1961) and multivariate statistical method (Mather and Doornkamp, 1970). GIS and remote sensing application have rolled away into dungeon of forgetfulness the stress associated to traditional method of enquiry into basin morphometry (Gabriel et al, 2019).

Morphometric analysis addresses statistical correlation of morphometric characteristics of drainage basin and basin hydrology. These types of statistical measure are developed to describe valley side, channel slopes, area, relief, drainage pattern type and extent of a basin. This analytical description of this physical division of landforms in a watershed is imperative to assess flash flooding susceptibility and basin management. It is fundamental for watershed prioritization for soil and water conservation, and water resources management. According to Farhan et al, (2016), it facilitates hydrological prospecting, assessment of the potential of groundwater recharge, and mapping of flood-prone areas. The study helps in understanding geomorphic evolution of drainage basins, landforms and slopes development (Hadley and Schumm, 1961). Other areas where the derived morphometric parameters notably compatible (dimensional and dimensionless) have registered application include the study of changing pattern of land form (Ward, 2007), flood hazard mapping (Diakakis, 2011), appraisal of hydrological potential of engaged basins (Ezemonye and Emeribe, 2013) and diastrophic studies (Sule and Bilewu, 2017). However, even with the fast opportunities remote sensing and GIS techniques avail, analytical description of the physical division especially, about drainage morphometric that influence flood (drainage density, drainage frequency, meandering ratio, stream order and bifurcation) relevant and appropriate for accurate planning of a catchment especially on River Taraba in the study area has not been documented. There are records of analysis of some basins in different parts of the globe outside Nigeria (Ward, 2007; Pankaj and Kumar, 2009; Hajam et al., 2013; Rama, 2014; Nanda et al., 2014) and in Nigeria (Ajibade et. al., 2010; Eze and Effiong, 2010; Ashaolu, 2016; Sule and Bilewu, 2017; Ikusemoran et.al, 2018). In the study area, concerns with natural hazards are much, however the studies in this regard are rare, but the increasing development of many catastrophic events in the last decades has raised the ideas of many researchers. River Taraba is one of the major tributaries of River Benue in 
Taraba. Despite its water resources prospective critical for socio-economic development of the region and Taraba state at large (Adebayo and Bashir, 2005; Adelalu, et al 2018), there are few available literature regarding the characterization of this river in the State to aid in the development, management and sustainability of the basin (Gabriel et.al, 2019). This present study attempts assessment of the hydrological response of the basins to morphometric parameters using Geospatial techniques.

\section{Study Area}

River Taraba is one of the major tributaries of River Benue in Taraba State. The basin lies between latitude $6^{0} 59^{1}$ and $8^{0} 39^{1}$ north of equator and between Longitude $10^{0} 19^{1}$ and $11^{0} 52^{1}$ east of the Greenwich Meridian in Taraba State (Fig. 1).It lies diagonally across central Taraba. The basin is bordered on the north by Mutum Biyu, on the east by Ghashaka and Maisamari, on the south by Donga and Sabongida, and on the west by River Benue. There exist nine sub-basins in the study area and these sub-basins network with the river and drain a total area of about $15777 \mathrm{~km}^{2}$ having perimeter of about $959 \mathrm{~km}$. The river traverses seven main towns in the middle region of the State before emptying to River Benue at the Western part of the State. The towns include, Bali, Gangumi, Gayam, Jamtari, Karamti SertiBaruwa, and SarkiRuwa. These areas are probable to flooding and could be gripped when impaired by encroachment through human activities in the region.

The study area is characterized by tropical continental climate marked by dry and wet seasons. Dry seasons last for a minimum of five months (November-March) while the wet seasons spans from April to October. Mean annual rainfall is less than $1000 \mathrm{~mm}$ in latitude $9^{\circ}$ (Adebayo, 2012) and 1350 $\mathrm{mm}$ recorded in the Southern part of the study area. The rainfall distribution pattern in the study area shows a decrease from the south to the northern part. Maximum temperature ranges between $26^{\circ} \mathrm{C}$ to $39^{\circ} \mathrm{C}$ while minimum temperature ranges between $15^{\circ} \mathrm{C}$ to $18^{\circ} \mathrm{C}$. 


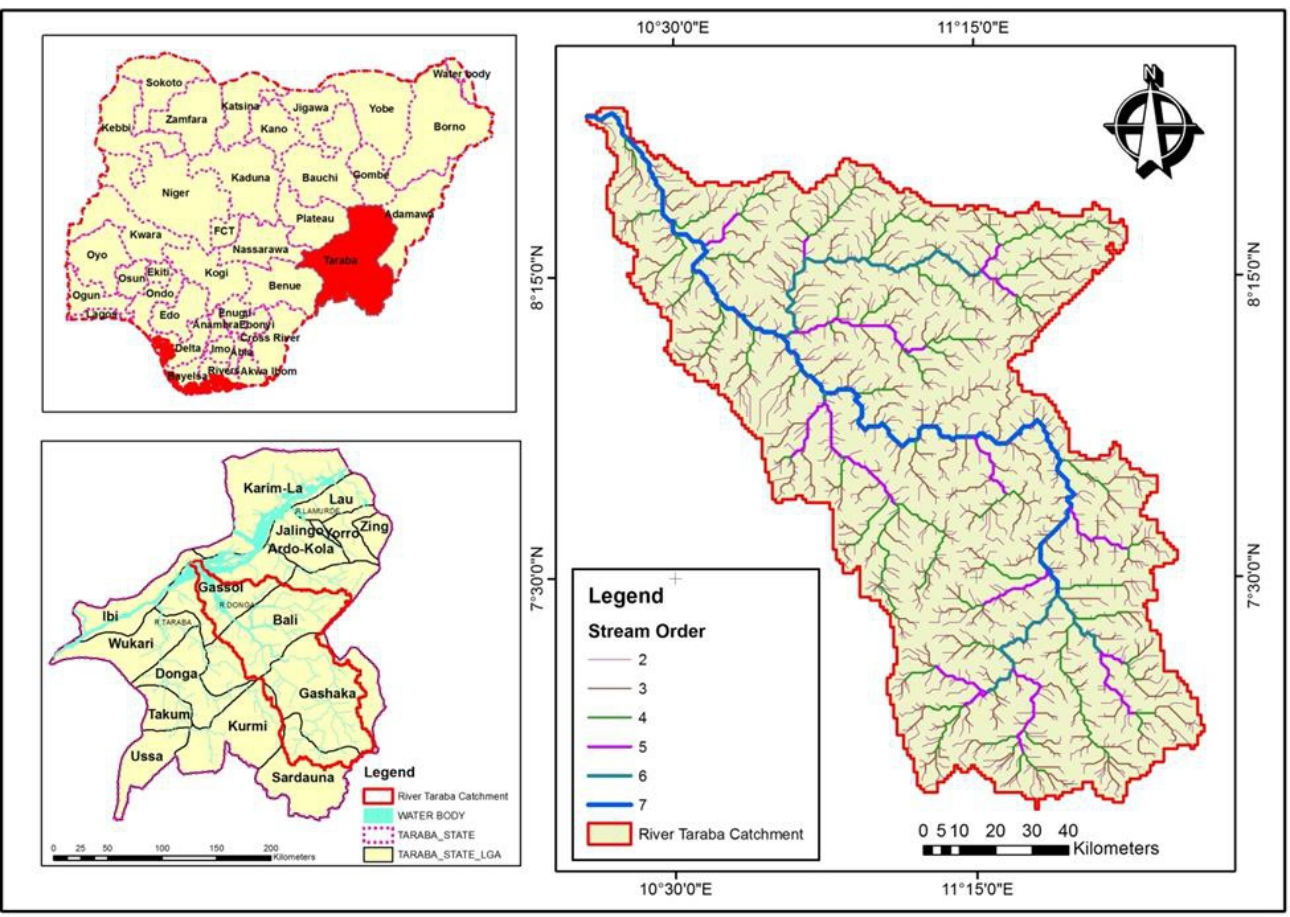

Figure 1: Catchments area of River Taraba

\subsection{Soil types of the study area}

The soil of the study area is a product of four primary factors: Climate, vegetation, lithology and topography (Oruonye, 2014). It can be classified into two major groups following the Food and Agriculture Organization (1974) genetic classification system. These are the ferruginous tropical soils and alluvial soils. The ferruginous tropical soil derived from crystalline acid rocks of the basement complex. Using the harmonized world soil database downloaded from the site Worldmap.havard.edu/data/geonade:DSMW_RdY depicts six different soil types (Fig 2). Among these are Dystric Fluvisols, Ferric Acrisols, Ferric Luvisols, Fluvisols, Lithosols, and Numic Nitosols. The soil ranges from deep well- drained dark red coarse stony sands and gravel on the higher pediment slopes surrounding the inselbergs and hills through shallow stony brown sandy fine gravels to deep moderately drained yellowishred concretionary loamy fine sands on the lower slopes (Carter et al.1963). 


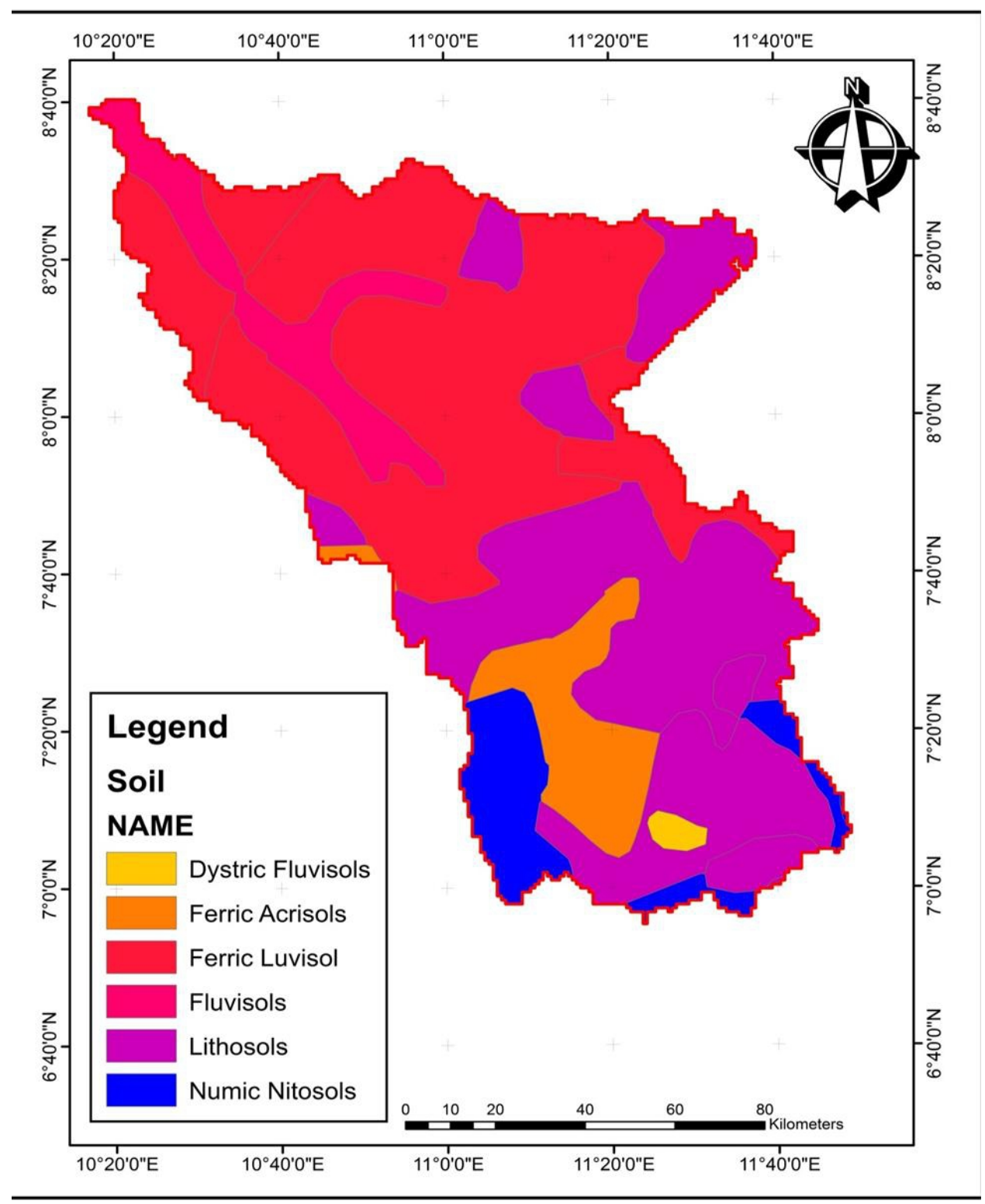

Fig 2: Soil types of RTCA

\subsection{Land use type of the study area}

Figure 3 shows the land use types of the study area. The result of the land use analysis for the catchment shows a natural vegetation cover of about $10902 \mathrm{~km}^{2}$, which is about $69.1 \%$ of the catchment area. Cultivated area and the bare land amount to about $3818 \mathrm{~km}^{2}$ about $24.2 \%$ of the basin area. Builtup area covers of about $1057 \mathrm{~km}^{2}$, occupy just $6.7 \%$. Owing to the incidence of large vegetation cover, which is more than half of the basin area, generally, one would have expected a low rate of flooding in the study area. Good 
coverage and lack of vegetation cover in some areas provide support evidence of a little flooding in some areas and high flooding in some area that are highly denuded. According to Kelemen and Blist'anova (2014), the susceptibility of a place on the world to flood is a function of the region's exposure to the hazard (natural event) and the anthropogenic activities (the extent of built-up; transformation on the terrain) which impede the free flow of water. Conversely, it can be said of the study area that the transformation is concentrated to flood plain as people place themselves in the path of geophysical agents. As the rainfall shorten (Adebayo, 2012) farming stakeholders migrate to the plain thereby, increases pressure on the watershed.

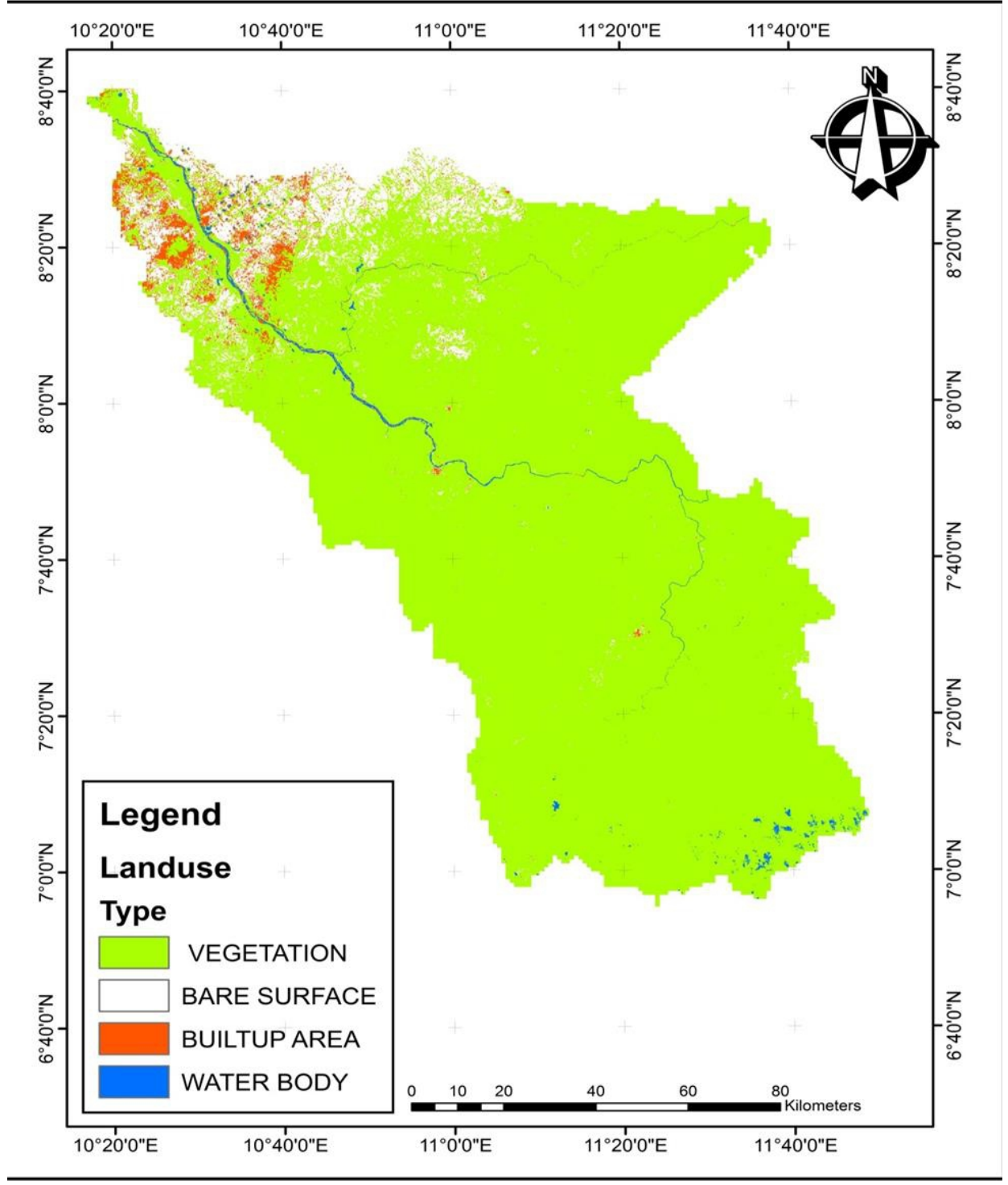

Fig 3: Land use types of RTCA 


\section{Materials and Method}

\subsection{Data Sources and Methodology}

Topo sheets that were used for this work include: SHEET 235, SHEET 255 and SHEET 256. The sheets were used initially to demarcate the boundaries of the watershed, then, the ArcHydro tool was utilized to delineate the final watershed boundaries and stream networks for the catchment. These maps with a scale 1:50 000 of the area published (1968) was obtained from the archive of Federal Surveys Department of Nigeria. Other materials explored for the actualization of the objective of this work include (i) Digital Elevation Model (DEM) of $30 \mathrm{~m}$ resolution. This DEM was acquired from the Shuttle Radar Topographic Mission (SRTM) available for the globe and downloaded from http://srtm.usgs.gov/data/obtaing.html. (ii) Soil image acquisition was from Digital soil map of the world (DSMW) http://Worldmap.havard.edu/data/geonade.html (iii) The geological profiles of RTCA was obtained from harmonization of the maps from two ministries of work: Federal surveys map of 1959 and the Geological Survey map of Nigeria in 1985.

ArcGIS tools were employed to derive, and calculate the morphometric characteristics of the watershed. Topographic feature for the study area such as drainage map, slope categories, elevation were generated using the Spatial Analyst module. The stream order maps were compiled from the flow direction map. Basic parameters of the basin such as: area (A), basin length $\left(\mathrm{L}_{\mathrm{b}}\right)$, perimeter $(\mathrm{P})$, stream order $(\mathrm{u})$, stream number $(\mathrm{Nu})$, stream length $\left(\mathrm{L}_{\mathrm{u}}\right)$, were measured directly from the DEM using GIS software while the derived parameters such as bifurcation ratio $\left(R_{b}\right)$, drainage density $\left(D_{d}\right)$, stream frequency $\left(\mathrm{F}_{\mathrm{s}}\right)$, length of overland flow $\left(\mathrm{L}_{\mathrm{o}}\right)$, circularity ratio $\left(\mathrm{R}_{\mathrm{c}}\right)$, elongation ratio $\left(R_{e}\right)$, basin relief $\left(B_{h}\right)$, relief ratio $\left(R_{r}\right)$, and form factor $\left(R_{f}\right)$ were calculated based on mathematical relations in Table1.

Table 1: The Morphometric parameters and their mathematical formula used for this study

\begin{tabular}{|l|l|l|}
\hline Morphometric Parameters & Methods & Reference \\
\hline Linear Aspects & & \\
\hline Stream order $(\mathrm{U})$ & Hierarchical rank & Strahler $(1964)$ \\
\hline Number of Streams $(\mathrm{Nu})$ & $\mathrm{Nu}=\mathrm{N} 1+\mathrm{N} 2 \ldots \ldots \mathrm{N}_{\mathrm{m}}$ & Horton $(1945)$ \\
\hline Stream length in km $(\mathrm{Lu})$ & $\mathrm{Lu}=\mathrm{L} 1+\mathrm{L} 2 \ldots \ldots \ldots \mathrm{L}_{\mathrm{m}}$ & Horton $(1945)$ \\
\hline Mean stream Length $\left(\mathrm{L}_{\mathrm{um}}\right)$ & $\mathrm{L}_{\mathrm{um}}=\mathrm{Lu} / \mathrm{Nu}$ & Strahler $(1964)$ \\
Bifurcation Ratio $\left(\mathrm{R}_{\mathrm{b}}\right)$ & $\mathrm{R}_{\mathrm{b}}=\mathrm{Nu} / \mathrm{Nu}+1$ & Schumm (1956) \\
Stream length Ratio $\left(\mathrm{R}_{\mathrm{L}}\right)$ & $\mathrm{R}_{\mathrm{L}}=\mathrm{Lu} / \mathrm{Lu}-1$ & Horton $(1945)$ \\
\hline Areal Aspects & & \\
\hline Area in km ${ }^{2}(\mathrm{~A})$ & Area calculation & Schumm $(1956)$ \\
\hline Perimeter in km $(\mathrm{P})$ & Perimeter calculation & Schumm (1956) \\
\hline Length of the basin in $\mathrm{km}\left(\mathrm{L}_{\mathrm{b}}\right)$ & Length calculation & Schumm $(1956)$ \\
\hline Drainage density $\left(\mathrm{D}_{\mathrm{d}}\right)$ & $\mathrm{D}_{\mathrm{d}}=\mathrm{Lu} / \mathrm{A}$ & Horton $(1932)$ \\
Stream frequency $\left(\mathrm{F}_{\mathrm{s}}\right)$ & $\mathrm{F}_{\mathrm{s}}=\mathrm{Nu} / \mathrm{A}$ & Horton $(1932)$ \\
Circulatory ratio $\left(\mathrm{R}_{\mathrm{c}}\right)$ & $\mathrm{R}_{\mathrm{c}}=12.57 *\left(\mathrm{~A} / \mathrm{P}^{2}\right)$ & Miller $(1953)$ \\
\hline
\end{tabular}




\begin{tabular}{|l|l|l|}
\hline Elongation ratio $\left(\mathrm{R}_{\mathrm{e}}\right)$ & $\mathrm{R}_{\mathrm{e}}=2 / \mathrm{Lb}^{*} \sqrt{ }(\mathrm{A} / \lambda)$ & Schumm (1956) \\
Form factor $\left(\mathrm{F}_{\mathrm{f}}\right)$ & $\mathrm{F}_{\mathrm{f}}=\mathrm{A} / \mathrm{Lb}^{2}$ & Horton $(1932)$ \\
Drainage intensity $\left(\mathrm{I}_{\mathrm{d}}\right)$ & $\mathrm{I}_{\mathrm{d}}=\mathrm{Fs} / \mathrm{Dd}$ & Faniran (1968) \\
Length of overland flow $\left(\mathrm{L}_{\mathrm{o}}\right)$ & $\mathrm{L}_{\mathrm{o}}=1 / \mathrm{Dd} * 0.5$ & Horton $(1945)$ \\
Lemniscate ratio $(\mathrm{K})$ & $\mathrm{K}=\mathrm{L}^{2} / 4 \mathrm{~A}$ & Chorely,et al., (1957) \\
& & \\
Relief Aspects & & Strahler (1957) \\
Basin relief in $\mathrm{m}(\mathrm{H})$ & $\mathrm{H}=\mathrm{Z}-\mathrm{z}$ & Schumm (1956) \\
Relief ratio $\left(\mathrm{R}_{\mathrm{h}}\right)$ & $\mathrm{R}_{\mathrm{h}}=\mathrm{H} / \mathrm{Lb}$ & Melton (1957) \\
Relative Relief $\left(\mathrm{R}_{\mathrm{hp}}\right)$ & $\mathrm{R}_{\mathrm{hp}}=\mathrm{H}^{*} 100 / \mathrm{P}$ & Strahler, (1964) \\
Ruggedness number $\left(\mathrm{R}_{\mathrm{n}}\right)$ & $\mathrm{Rn}=\mathrm{Dd} *(\mathrm{Bh} / 1000)$ & Strahler, (1964) \\
\hline
\end{tabular}

\section{Results and Discussion}

\subsection{Drainage Network of RTCA}

\subsubsection{Stream Order, Stream number $\left(N_{u}\right)$ and Bifurcation Ratio $\left(R_{b}\right)$}

Fig. 4 shows the axial divides, links and lay out of the stream and the basin. Table 2 shows the results of the linear features of morphometric parameters for the RTCA.

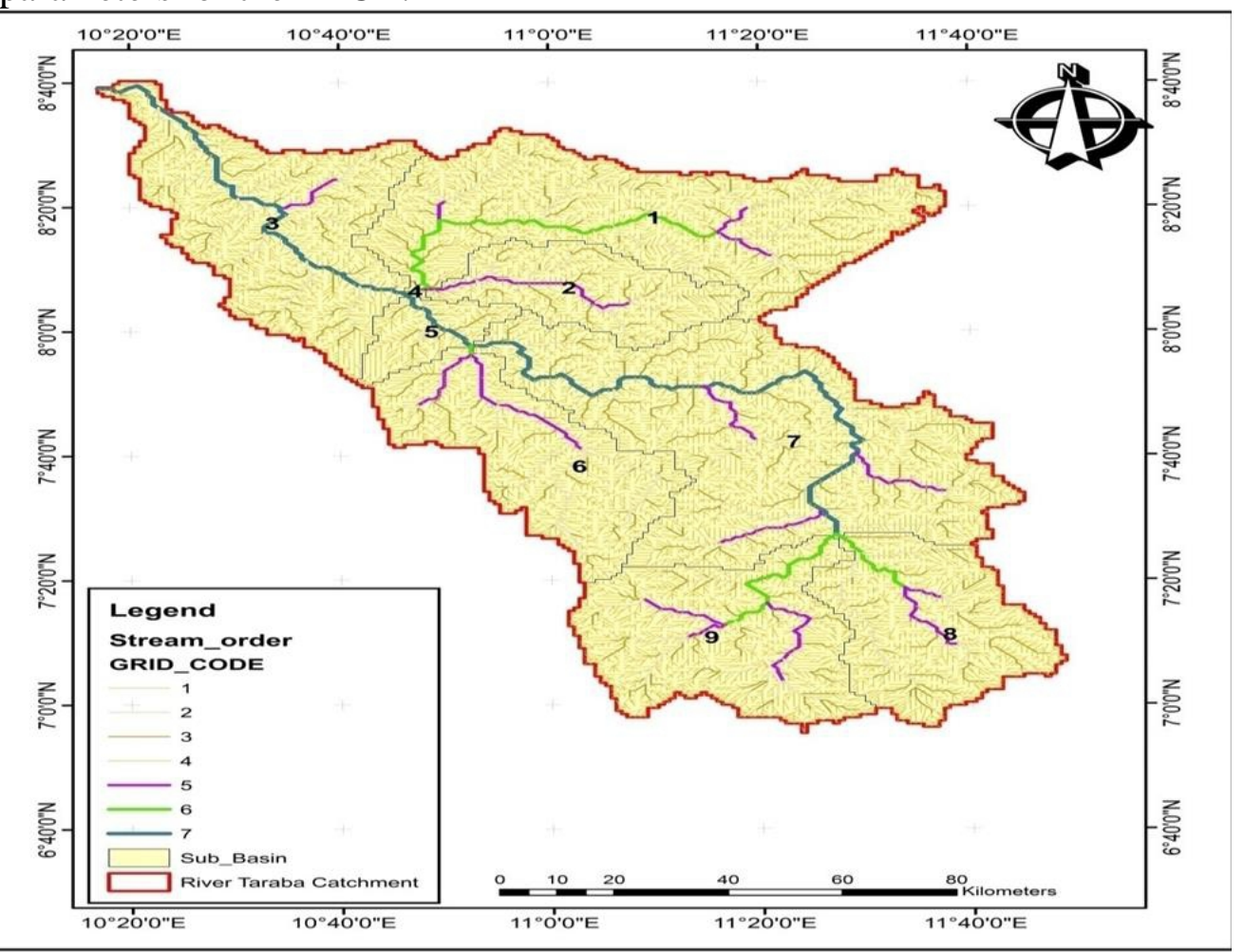

Fig 4: Stream order of the RTCA

The highest order obtained using the DEM is $7^{\text {th }}$ order. So the basin is designated as $7^{\text {th }}$ order drainage basin. The total number of streams $\left(\mathrm{N}_{\mathrm{u}}\right)$ for the nine watersheds is 9205 , and the first order streams account for $80.2 \%$ of 
the total number of streams in the basins. As it is common to all drainage basins, the number of streams gradually decreases as the stream order increases. Stream length (Lu) is a significant hydrological property and indicative of runoff characteristics, geomorphic development of stream segments, and tectonic instability. In most of the studies of river basins, it is observed that the higher the order, the longer the length of stream. The stream length has been calculated according to the law elaborated by (Horton, 1945). The total stream length varies between $267 \mathrm{~km}$ to $12893 \mathrm{~km}$ for the catchments under study. The first order streams constitute $67 \%$ of the total stream length. The stream length characteristics of river Taraba also confirm Horton's second law (Horton, 1945). Mean stream length $\left(\mathrm{L}_{\mathrm{sm}}\right)$ value recorded for the catchment is 2.09. Stream length ratio $\left(\mathrm{R}_{\mathrm{L}}\right)$ is the ratio between the mean lengths of streams of a given order to the mean length of streams in the next lower order. $\mathrm{R}_{\mathrm{L}}$ is considered as a significant factor in relation to both drainage composition and geometric development of drainage basins (Horton, 1945). Not much variation is noticeable in $\mathrm{R}_{\mathrm{L}}$ values between the streams of different orders pertaining to catchments except between stream order 6 and 7.Bifurcation ratio is elaborated by Balogun et al., (2013) and Bharadwaj et al., (2014) as an indicator of the complexity and degree of dissection of a drainage basin. In Taraba river Basin Bifurcation ratio ranges from 3.0 to 5.14 with $\mathrm{R}_{\mathrm{b}} 4.31$. Iron, (1985) posited three different Bifurcation ratio categories : Bifurcation ratio $<3$ indicates flat region, between 3 and 5 bifurcation describe geological structure which do not distort the drainage pattern as such and $>5$ bifurcation is a drainage network which are litho logically and structurally controlled. High bifurcation figures denote that drainage development of the watersheds is remarkably influenced by structural disturbances. Low values of $\mathrm{R}_{\mathrm{b}}$ in River Taraba watershed is representative for homogeneous bedrock (Chorley 1969 and Waugh 1996). It suggests that River Taraba is structurally less disturbed, with little or no distortion in drainage pattern. Disturbance such as warping, alternating high rounded hills and intervening flat topped ridges and rejuvenation of the drainage network are not clear cut in the study area as such.

Table 2: Linear Features of RTCA

\begin{tabular}{|c|c|c|c|c|c|c|c|}
\hline $\begin{array}{l}\text { STREAM } \\
\text { ORDER }\end{array}$ & $\begin{array}{l}\text { NO OF } \\
\text { STREAM }\end{array}$ & $\begin{array}{l}\text { TOTAL } \\
\text { STREAM } \\
\text { LENGTH(KM) }\end{array}$ & $\begin{array}{l}\text { MEAN } \\
\text { STREAM } \\
\text { LENGTH }\end{array}$ & $\begin{array}{l}\text { BIFUCATION } \\
\text { RATIO }\end{array}$ & $\begin{array}{l}\text { STREAM } \\
\text { LENGTH } \\
\text { RATIO }\end{array}$ & $\begin{array}{l}\text { MEAN } \\
\text { BIFURICATION }\end{array}$ & $\begin{array}{l}\text { LENGTH OF } \\
\text { OVERLAND } \\
\text { FLOW }\end{array}$ \\
\hline 1 & 7386 & 12893.3 & 1.75 & - & 0.26 & \multirow[t]{7}{*}{4.31} & \multirow[t]{7}{*}{1.64} \\
\hline 2 & 1435 & 3431.15 & 2.39 & 5.14 & 0.42 & & \\
\hline 3 & 302 & 1468.32 & 4.86 & 4.73 & 0.49 & & \\
\hline 4 & 62 & 722.13 & 11.65 & 4.79 & 0.41 & & \\
\hline 5 & 15 & 302.93 & 20.20 & 3.88 & 0.13 & & \\
\hline 6 & 4 & 39.58 & 9.90 & 3.0 & 6.73 & & \\
\hline 7 & 1 & 266.58 & 266.58 & - & & & \\
\hline TOTAL & 9205 & 19242.86 & & & & & \\
\hline
\end{tabular}




\subsection{Area Features and RTCA}

Values of the Area features of the RTCA are listed in Table 3. Area features are measure of the basin geometry. According to (Ayoade, 1988), it has important control over the geometry of the stream network thus influence the shape of the hydrograph. The shape of the basin determines the lag time and the period of ascend among other hydrograph parameters. A number of indices were used to depict the watersheds' shape. Such considered were the circularity ratio $\left(R_{c}\right)$, elongation ratio $\left(R_{e}\right)$, lemniscates ratio $(K)$ and form factor $\left(\mathrm{F}_{\mathrm{f}}\right)$. Others include Areal aspects that relate to texture of the drainage topography. These indices are drainage density $\left(\mathrm{D}_{\mathrm{d}}\right)$, stream frequency, drainage intensity $\left(\mathrm{I}_{\mathrm{d}}\right)$, length of overland flow $\left(\mathrm{L}_{\mathrm{o}}\right)$.

\subsubsection{Circularity $\left(R_{c}\right)$, Elongation $\left(R_{e}\right)$, and Lemniscates ratio $(K)$}

The circularity ratio of almost 0.22 is a suggestion that the River Taraba basin is not circular in shape. The elongation ratio of 0.58 is an evidence of the fact that the basin is not circular. Sule and Bilewu (2017), posited that categorization index for elongation ratio ranges from less than 0.5 - 1.0. Chow (1988) had earlier submitted that strongly elongated basins have circularity ratios of between 0.40 and 0.50 . Singh and Singh (1997) subscribed that a circular basin is more efficient in runoff than an elongated one. $R_{\mathrm{e}}$ value for River Taraba is greater than $0.5(0.58)$ (Table 3). This means the basin is elongated or less elongated with low relief and mild slopes. This implies that catchment show longer time to peak. It means basin produce a flatter peak of direct runoff for a longer duration. What then brings about the continuous yearly flooding of ever increasing magnitude? Lemniscates ratio (k) describes how closely the actual drainage basin shape approaches the loop of a lemniscates ( Ivanova et al, 2012). It is considered a useful index to distinguish one morphometric region from another, and to express quantitatively the structural control over basin shape. The $\mathrm{k}$ value for River Taraba catchment area is 0.925 . The value indicates that River Taraba catchment is less elongated and has a less delayed time to peak flow.

\subsubsection{Form factor $\left(F_{f}\right)$ and Stream frequency $\left(F_{s}\right)$}

Morphological characteristic of a watershed like form factor has powerful influence on watershed hydrology. $\left(\mathrm{F}_{\mathrm{f}}\right)$ has been elaborated by Horton (1945) to forecast the flow intensity of river basins. According to him, it is the relative amount of the area of basin (A) vis -a- vis the square of the basin length $\left(\mathrm{L}_{\mathrm{b}}\right)$. Catchments with low $\left(\mathrm{F}_{\mathrm{f}}\right)$ value tend to be elongated, which give low peak flows for longer duration, and thus reduce the chance for the basin to flood. On the contrary, catchments with high $\left(\mathrm{F}_{\mathrm{f}}\right)$ values experience high peak flow of short duration. Catchment with high $\left(\mathrm{F}_{\mathrm{f}}\right)$ gives flood of stronger and advanced velocities associated with bigger erosion capacities. 
The $\left(\mathrm{F}_{\mathrm{f}}\right)$ values for the nine sub-basins in the RTCA ranges from 0.18 to 0.27 . These values indicate that basins under study are more elongated and elongated in shape with low peak flows of longer duration.(Horton, 1932) define Stream frequency (Fs) as the total number of stream partitions of all levels within the basin per unit area. (Fs) is a suggestive of stream network allotment over the river basin. (Fs) ranges from less than 1 to 6 or even more depending on the lithology of the basin (Kale and Gupta, 2001). There exist relationship between (Fs) and flood potential of an area. Sreedevi et al, (2013), confirmed that high (Fs) means more percolation with respect to drainage density and thus more groundwater potential. The observed stream frequency (Fs) value for the River Taraba is 0.58. This implies gentle slopes, with intermediate permeability rocks, thus make possible moderate infiltration and less erosive surface flow and consequently, less flooding. Low (Fs) in RTCA is an indication that the catchment possesses a low relief and almost a flat topography.

\subsubsection{Drainage density $\left(D_{d}\right)$ and Drainage intensity $\left(I_{d}\right)$}

Drainage density $\left(D_{d}\right)$ is the total length of stream per unit area divided by the area of the basin (Horton, 1945). High $D_{d}$ values denote high runoff and low infiltration rate (Farhan and Ayed, 2017).Drainage density has been associated to the presence of impervious underlying bedrocks, spare plants, and hilly relief. On the contrary, low drainage density implies low runoff, low relief, high infiltration and groundwater recharge. The calculated value of $D_{d}$ for River Taraba is $1.22 \mathrm{~km} / \mathrm{km}^{2}$. Low $D_{d}$ obtained in RTCA suggests that the catchment have a high percentage of permeable underlain and good vegetable cover (Nageswara et al., 2010). It therefore expected that runoff from the catchment should be moderate (Raghunath, 2008). In fact at the time of this write up the warning again have been issued that people at Santride and Natride, mostly farmers at Gassol should move out of their farming areas to prevent the looming flood.

Table 3: Area Aspects of RTCA

\begin{tabular}{|l|l|}
\hline BASIN AREA & $15777 \mathrm{~km}^{2}$ \\
\hline BASIN PERIMETER & $959 \mathrm{~km}$ \\
\hline BASIN LENGTH & $242 \mathrm{~km}$ \\
\hline FORM FACTOR & 0.27 \\
\hline ELONGATED RATIO & 0.58 \\
\hline CIRCULATION RATIO & 0.22 \\
\hline DRAINAGE DENSITY & 1.22 \\
\hline STREAM FREQUENCY & 0.58 \\
\hline LEMINISCATE RATIO & 0.008 \\
\hline CONSTANT CHANNEL MAINTENANCE & 0.82 \\
\hline DRAINAGE TEXTURE & 9.59 \\
\hline
\end{tabular}




\subsection{Relief Parameters for the Watersheds}

4.3.1 Basin relief in $\mathrm{m}(\mathrm{H})$, Relief ratio $(\mathrm{Rh})$ and Ruggedness Numbers (Rn)

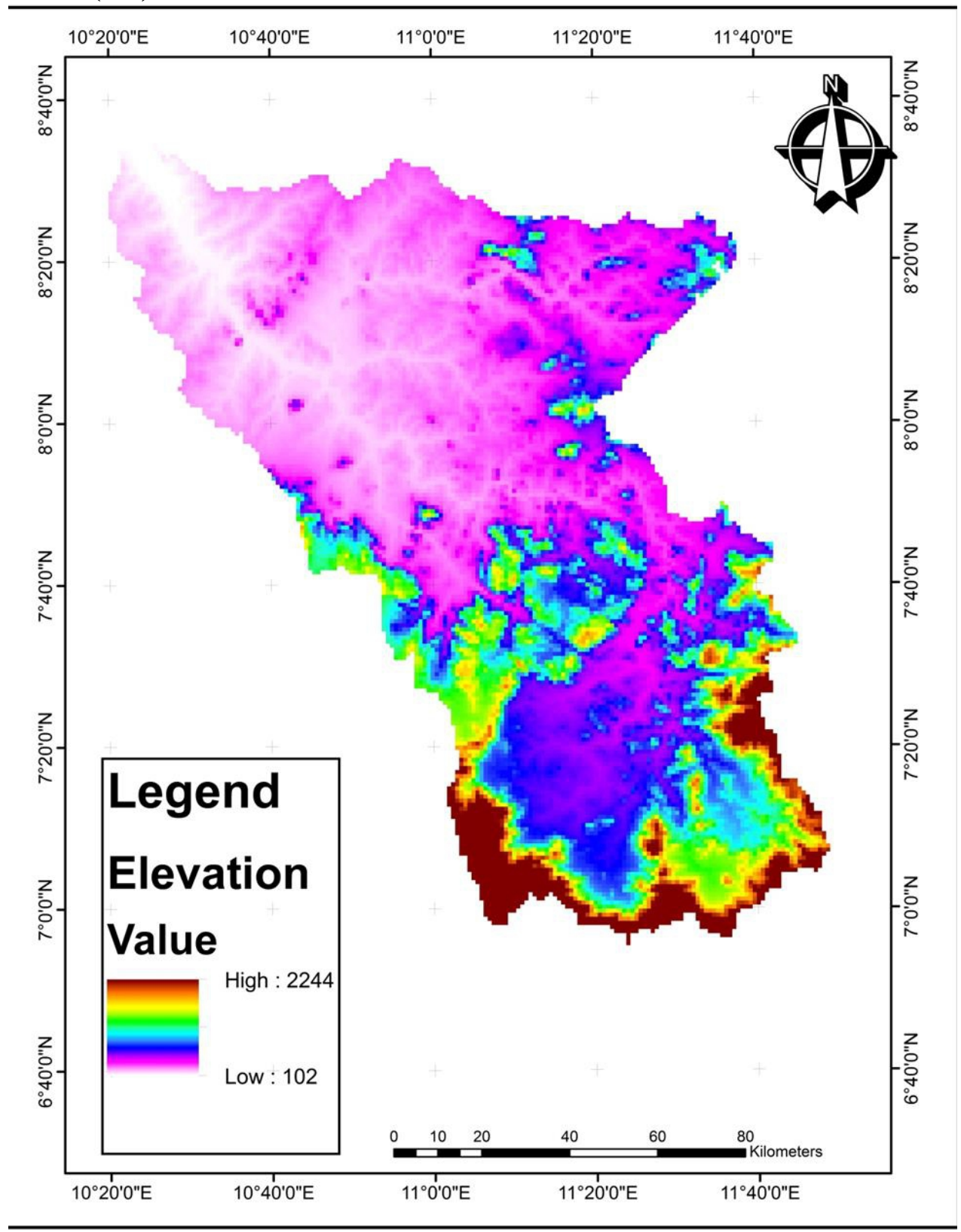

Fig 5: The digital elevation model of RTCA

Elevation difference between the lowest and the highest point of a given catchment area is term basin relief. Strahler,(1964) posited that relief measures are indicative of the likely energy of a drainage system present by 
virtue of elevation above a given datum. Relief is fundamental in understanding the denudation features of any catchment, landforms and drainage networks evolution, overland flow, through flow, and erosional behaviour of the catchment (Farhan, et al., 2016). The total relief of the River Taraba catchments varies from $103 \mathrm{~m}$ to $2244 \mathrm{~m}$. The lowest point (pour point) located at Natride while the maximum height is found at Gembu. According to Schumm (1956), relief ratio $\left(R_{h}\right)$ was defined as the total relief of the catchment and the longest dimension of the basin parallel to the principal drainage line. The $R_{h}$ value for the basin is 9.28 (Table 4).Low value of $R_{h}$ as depicted in River Taraba basin indicates the predominance of slow erosion processes. Ruggedness number $(\mathrm{Rn})$ is a dimensionless parameter representing the product of basin relief $(\mathrm{Bh})$ and the drainage density divided by1000 (Strahler, 1952). The works of Patton and Baker (1976) elaborates the index's worth to measure the flash flood potential of a drainage basin while Sujatha, et al.,(2013) exemplifies the geometric features of drainage basins concern. High value of $\mathrm{R}_{\mathrm{n}}$ is obtained when both relief and drainage density are large. River Taraba depicts a low (Rn) of about 2.74.

Table 4: Relief aspect of RTCA

\begin{tabular}{|c|c|c|c|c|}
\hline $\begin{array}{l}\text { HEIGTH OF } \\
\text { BASIN } \\
\text { MOUTH } \\
\text { (meter) }\end{array}$ & $\begin{array}{l}\text { MAXIMUM } \\
\text { HEIGTH OF } \\
\text { THE BASIN }\end{array}$ & $\begin{array}{l}\text { TOTAL } \\
\text { BASIN } \\
\text { RELIEF }\end{array}$ & $\begin{array}{l}\text { RELIEF } \\
\text { RATIO }\end{array}$ & $\begin{array}{l}\text { RUGGEDNESS } \\
\text { NUMBER }\end{array}$ \\
\hline 103 & 2244 & 2142 & 9.28 & 2.74 \\
\hline
\end{tabular}

\section{Conclusion and Recommendation}

Morphometric analysis carried out for river Taraba confirms the presence of nine sub basins. There is no pronounced variation in the geomorphometric attributes characterizing the catchment. Drainage density (Dd), relief ratio $\left(R_{h}\right)$, elongation ratio $(R e)$, circularity ratio $(R c)$ and ruggedness number $(\mathrm{Rn})$ are intermediate. Medium values of bifurcation ratio in the basin indicate transitional zone of geological structure with a less significant influence of structural instability. The overall mean bifurcation ratio was low. This is a suggestion that the landforms and geology of the study area do not vary from basin to basin. Rainfall to runoff ratio is expected to be mild and moderate. Invariably, the variation in the conversion of rainfall into runoff from one catchment to another will depend much on the exposure or denudation activities on the basins. RTCA is dendritic. The longer the basin length the little the influence on the extent to which the surface runoff manoeuvre the basin and been lowered by agents of denudation. Charaterizations of the RTCA from basin morphometry do not demonstrate high flooding susceptibility especially in terms of low mean catchment slope, low drainage density $(D d)$ and stream frequency $\left(\mathrm{F}_{\mathrm{s}}\right)$. Variations in morphometric and morphological characteristics of this catchment have not 
notably influenced the potential of flash floods occurrence. Previous losses incurred through flood in this region seem self-induced. This occurred as local community dwellers placed themselves in the path of geophysical agents through encroachment. In summary, environmnetal degradation through profiliration of haphazard and uncontrolled development within and around the flood plain seem the cause of incessant flooding in major parts of the catchment.

It is therefore recommended that human activities that could impact negatively on the drainage network should be discouraged. Governments sholud discourage influx to buffer and exploitation of the drainage basin in the study area.

\section{References:}

1. Adebayo, A.A (2012). Evidence of Climate Change in Taraba State: A Preliminary Report. A Paper Presented at the Faculty of Science Seminar Series, Taraba State in Jalingo 13 ${ }^{\text {th }}$ of September 2012.

2. Adebayo, A.A, \&Bashir B.A. (2005).Hydrology and water resources.In Tukur AL, Adebayo A.A, Galtima M (Ed.).The land and People of the Mambilla Plateau.

3. Adelalu, T.G; Ibrahim, A \&Alade, E.J (2018).Rainfall variation, water resources potential andimplication for flooding: A case study of catchmentarea of major tributaries to River Benue in Taraba State. African Journal of Engineering Research Vol. 6(3), pp. 55-63, DOI: 10.30918/AJER.63.18.028

4. Ajibade, L, TIfabiyi, I.P, Iroye K.A, \&Ogunteru, S.( 2010). Morphometric analysis of Ogunpa and Ogheredrainage basins, Ibadan, Nigeria.Ethiopia Journal of Environmental Studies and Management. 1:13-19.

5. Ashaolu, E.D. (2016).The Osun drainage basin in the western lithoral hydrological zone of Nigeria: A morphometric study. Malaysian Journal of Society and Space. 12(8): 71-88.

6. Ayoade, J. O. (1988). Tropical hydrology and water resources.London: Macmillan.

7. Balogun, I., Adegun, O., Ayodele, D., Adega, O., \&Okah, G. (2013).Geometric characteristics of Olomore drainage basin, Abeokuta, and their implications for hydrologic processe.Lagos Journal of Geo-Information Sciences (LJGIS) Volume 3, Number1, Aug. 2013.

8. Bharadwaj, A.K., Pradeep, C., Thirumalaivasan, D., Shankar, C.P. \&Madhavan, N. (2014). IOSR Journal of mechanicaland civil engineering (IOSR-JMCE) e-ISSN: 2278-1684, p- ISSN: $\quad 2320$ 334X. pp71-77. 
9. Carter, J.D., Barber, W. \&Tait, E.A.(1963). "The geology of parts of Adamawa, Bauchi and Bornu Provinces in Northern Nigeria". Bull. No. 30, Geol. Surv.Of Nigeria, 108.

10. Chorley, R. J. (1969). The drainage basin as the fundamental geomorphic unit.In R. J. Chorley (Ed.), Water, earth, and man: a synthesis of hydrology, geomorphology and socio- economic geography (pp. 77 -99).London:Methuen.

11. Chorley, R. (1971) The Drainage Basin as the Fundamental Geomorphic Unit. In: Chorley, R., Ed., Introduction to Fluvial Processes, Methuen and Co. Ltd., London, 30-32.

12. Diakakis, M.(2011). A Method for Flood Hazard Mapping Based on Basin Morphometric: Application in Two Catchments in Greece. Natural hazards, Volume 56, pp803-814.

13. Eze, E.B,\&Effiong, J.( 2010). Morphometric parameters of Calarbar river Basin: Implication for hydrological progress. Journal of Geography and Geology. 2(1):18-26.

14. Ezemonye, M.N \&Emeribe, C. N (2013).Appraisal of the Hydrological Potential of ungauged Basin using Morphometric Parameters. Ethiopian Journal of Environmental Studies and Management, Volume 6, No 4, pp 376-380.

15. Farhan, Y., Anaba, O. \&Salim, A. (2016) Morphometric Analysis and Flash Floods Assessment for Drainage Basins of the Ras En Naqb Area, South Jordan Using GIS. Journal of Geoscience and Environment Protection, 4, 9-33.

http://dx.doi.org/10.4236/gep.2016.46002

16. Farhan, Y. \&Ayed, A. (2017) Assessment of Flash-Flood Hazard in Arid Watersheds of Jordan.Journal of Geographic Information System, 9, 717-751. https://doi.org/10.4236/jgis.2017.96045

17. Food and Agriculture Organization, (1974).The FAO-Unesco Soil Classification System.The World Refernce Base for soil resources Diagnostic horizons properties and materialsg.

18. Gabriel, T. A., Yusuf, M. B., Ibrahim, A \& Idakwo, V.I (2019). Morphometric Analysis of River Donga Watershed in Taraba State Using Remote Sensing and GIS Techniques. Journal of Geography, Environment and Earth Science International 20(3): 1-13.

19. Hadley, R. \&Schumm, S. (1961) Sediment Sources and Drainage Basin Characteristics in Upper Cheyenne River Basin. US Geological Survey Water-Supply Paper 153-B, Washington DC, 198.

20. Hajam RA, Hamid A, Ahmad DN, Bhat SU. (2013).Morphometric analysis of vishav drainage basin using geo-spatial tecnology (GST).International Research Journal of Geology and Mining. 
3(3):136-146.

21. Horton, R. (1945) Erosional Development of Streams and Their Drainage Basins: Hydrological Approach to Quantitative Morphology. Geological Society of America Bulletin, 56, 275-370. https://doi.org/10.1130/0016-7606(1945)56[275:EDOSAT]2.0.CO;2

22. Horton, R. E .(1932). Drainage-basin characteristics. Trans. Am. Geophys. Union, 13, 350-361.

23. Ikusemoran, M., Manu, H., \&Yelwa, A.B.(2018). Geospatial Analysis of Morphometric Characteristics of River Hawul Basin, North-East Nigeria.Resources and Environment. 8(3): 103-126.

DOI: $10.5923 /$ j.re.20180803.03

24. Iron, Z. (1985).Basin Hydrology.Vol 20. Retrieved from https://www.sciencedirect.com/science/article/pii/S0167564 808704131 on 23/03/2019.

25. Ivanova, E., Nedkov, R., Ivanova, I. \&Radeva, K. (2012) MorphoHydrographic Analysis of Black Sea Catchment Area in Bulgaria.Procedia Environmental Sciences, 14, 143-153. http://dx.doi.org/10.1016/j.proenv.2012.03.014

26. Kale VC, Gupta A. (2001).Introduction to geomorphology, New Delhi: Academic (India) Publishers.

27. Kelemen, M., \&Blist'anova, M (2014). Logistic Modeling to handle the treat of flood- The Bodva River example,In: SGEM; $14^{\text {th }}$ International Multidisciplinary Sciencetific Geo Conference: Conference Proceedings: Volume III: 17-26 June held in Bulgaria.

28. Mather, P.\&Doornkamp, J. (1970) Multivariate Analysis in Geography.Transactions of the Institute of British Geo- graphers, 51, 163-187. http://dx.doi.org/10.2307/621768

29. Nageswara, R.K., Swarna, L.P., Arun, K.P., \&Hari K. (2010).Morphometric Analysis of gostaniRiver Basin in Andra Pradesh State, Indian using spatial Information technology. International Journal of geomatics and geosciences, Vol. 1, No 2, pp 179-187.

30. Nanda, A.M., Ahmed, P., Kanth, T.A.,\&Hajam, R.A ( 2014). Morphometric Analysis of Sandran Drainage Basin (J\&K) using Geospatial Technology. Earth Science Indian, Vol. 7No 2, pp 55-66.

31. Oruonye, E.D (2014).Climate Change Perception Among Rural Farmers in Taraba State Nigeria.Phimela Publishing and Printing Press, Jalingo.

32. PankajA,\&Kumar P. (2009). GIS based morphometric analysis of five sub watershed of Song River, Dehradun district, uttarak-hand with special reference to landslide incidences. Journal of Indian Society of Remote Sensing. 37:157-166. 
33. Patton, P. \& Baker, V. (1976) Morphometry and Floods in Small Drainage Basis Subject of Diverse Hydrogeomorphic Controls. Water Resources Research , 12, 941-952. https://doi.org/10.1029/WR012i005p00941

34. Raghunath, H. M.( 2008). Hydrological Principles. New Age international limited. ISBN 81224-1825-2,Delhi

35. Rama, V.A.(2014). Drainage basin analysis for characterizations of 3rd order watersheds usinggeographic information system (GIS) and ASTER data. Journal of Water Resources and Protection. 2014;4:1042-1050.

36. Schumm, S.A. (1956) Evaluation of Drainage System and Slopes in Badlands at Perth Amboy, New Jersey.Geological Society of America Bulletin, 67, 597-646. http://dx.doi.org/10.1130/00167606(1956)67[597:EODSAS]2.0.CO;2

37. Singh S, Singh MC.(1997). Morphometric analysis of Kanhar river basin, Nat Geographical Journal of India.43(1):31-43.

38. Strahler, A.N. (1957) Quantitative Analysis of Watershed Geomorphology. Transactions, American Geophysical Un- ion, 138, 913-920. http://dx.doi.org/10.1029/TR038i006p00913

39. Sreedevi, P.D., Sreekanth, P.D., Khan, H.H \& Ahmad, S. (2013) Drainage Morphometry and Its Influence on Hydrology in anSemi Arid Region: Using SRTM Data and GIS. Environmental Earth Sciences, 70, 839-848. http://dx.doi.org/10.1007/s12665-012-2172-3

40. Strahler, A.N. (1952) Dynamic Basis of Geomorphology. Geological Society of America Bulletin, 63, 923-938. http://dx.doi.org/10.1130/0016-7606(1952)63[923:DBOG]2.0.CO;2

41. Strahler, A.N. (1964) Quantitative Geomorphology of Drainage Basinsand Channel Networks. In: Chow VT, (ed.) Handbook of applied hydrology. McGraw-Hill, New York. 1964; 439-476.

42. Sule, B.F,\&Bilewu S.O. (2017). A morphometric study of five selected drainage basins in Nigeria. FuLafia Journal of Science \& Technology. 2017;3(1).

43. Sujatha, E., Selvakumar, R., Rojasimman, U. \& Victor, R. (2013) Morphometric Analysis of Sub-Watersheds in Part of Western Ghats, South India Using ASTER DEM. Geomatics, Natural Hazards and Risk, 6, 326-341. https://doi.org/10.1080/19475705.2013.845114

44. Sreedevi, P.D.,Sreekanth, P.D., Khan, H.H. \& Ahmad, S. (2013) Drainage Morphometry and its Influence on Hydrology in a Semi Arid Region: Using SRTM Data and GIS. Environmental Earth Sciences, 70, 839-848. https://doi.org/10.1007/s12665-012-2172-3 
45. Ward, J.V. (2007). Changing patterns of land use and basin morphometry: Impacts on stream geomorphology in the IILinois River Basin, Northwest Arkansas, 1941-2004, University of Arkansas, USA.

46. Waugh, D. (1995). Geography: An integrated approach. Thomas Nelson and Sons Ltd. NY. P320.

47. Waugh, D. (1996). Geography: an integrated approach. New York: Nelson (Chapter 6)

48. Yousif, M. \&Bubenzer, O. (2015) Geoinformatics Application for Assessing the Potential of Rainwater Harvesting in Arid Regions. Case Study: El Daba'a Area, Northwestern Coast of Egypt. Arab Journal of Geosciences , 9, 9169-9191.

https://doi.org/10.1007/s12517-015-1837-0 